\title{
LONG-TERM MEASUREMENT OF BLACK CARBON CONCENTRATION AND SOURCE APPORTIONMENT ANALYSIS
}

\author{
Adnan Masic, Goran Kepnik, Dzevad Bibic, Elmedin Mesic \& Boran Pikula
}
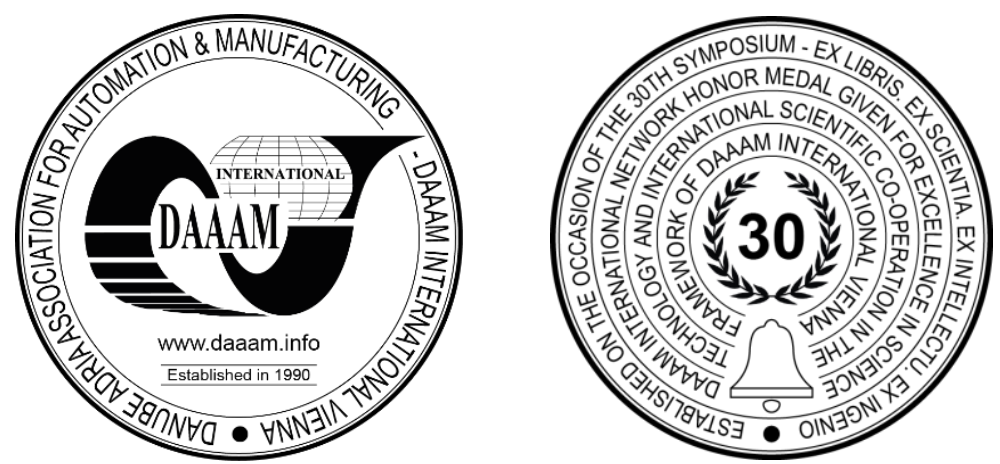

This Publication has to be referred as: Masic, A[dnan]; Kepnik, G[oran]; Bibic, D[zevad]; Mesic, E[1medin] \& Pikula, B[oran] (2021). Long-term Measurement of Black Carbon Concentration and Source Apportionment Analysis, Proceedings of the 32nd DAAAM International Symposium, pp.0131-0135, B. Katalinic (Ed.), Published by DAAAM International, ISBN 978-3-902734-33-4, ISSN 1726-9679, Vienna, Austria DOI: $10.2507 / 32$ nd.daaam.proceedings.020

\begin{abstract}
Continuous measurement of black carbon (BC) concentrations in ambient air was performed using the optical-based instrument called aethalometer. The attenuation of light by BC was measured at 7 different wavelengths. This gives not only the pure concentration of $\mathrm{BC}$ in the ambient air but also dependence of attenuation on the wavelength of light, from which the Angstrom exponent can be derived. Based on the Angstrom exponent, we can estimate the percentage of BC that originates from solid fuel (wood and coal burning) or liquid fuel (diesel). Thus, a simple source apportionment analysis is presented.
\end{abstract}

Keywords: black carbon; source apportionment; fossil fuels; biomass burning.

\section{Introduction}

Aerosol black carbon $(\mathrm{BC})$ is a very important component of air pollution. It originates from incomplete combustion of fossil fuels and has deep effects on climate. It is argued that $\mathrm{BC}$ is the second largest anthropogenic climate change factor [1], [2] (carbon dioxide being first). The negative health effects of black carbon are well documented [3], [4]. Thus, the research on black carbon is a very significant step towards decarbonization. Previous research articles include Evaluation with a Photoacoustic Instrument [5], method comparisons [6], vertical profiles over Milan [7], diesel exhaust [8], wood combustion particles [9], emissions from fresh biomass burning [10], and source apportionment [11]. The novelty in this article is the long-term campaign of continuous BC measurement with source apportionment analysis.

\section{The aethalometer}

The instrument for the measurement of BC concentration is called aethalometer (the word comes from the classical Greek verb aethaloun which means "to blacken with soot"). The AE33 aethalometer, Magee Scientific, USA (Figure 1) is used in this research. The main specifications of AE33 are:

- 7 measurement wavelengths: 370, 470, 520, 590, 660, 880 and $950 \mathrm{~nm}$,

- Airflow: set-points of 2, 3, 4, and 5 LPM,

- Max power consumption: $90 \mathrm{~W}$. Typical power consumption: $25 \mathrm{~W}$. 
Figure 2 shows the flow diagram of AE33. The inlet cyclone, at the beginning of the air sampling line, separates particles greater than $2.5 \mathrm{~mm}$ in diameter. $\mathrm{BC}$ particles are collected on filter tape and the light absorption method is used to calculate $\mathrm{BC}$ concentration at $880 \mathrm{~nm}$ of wavelength, as described in our previous work [12]. The black carbon facility is one component of a larger project of our research group, where different aspects of air pollution are observed and compared, including toxic gases [13], [14], and particulate matter [15]-[21].

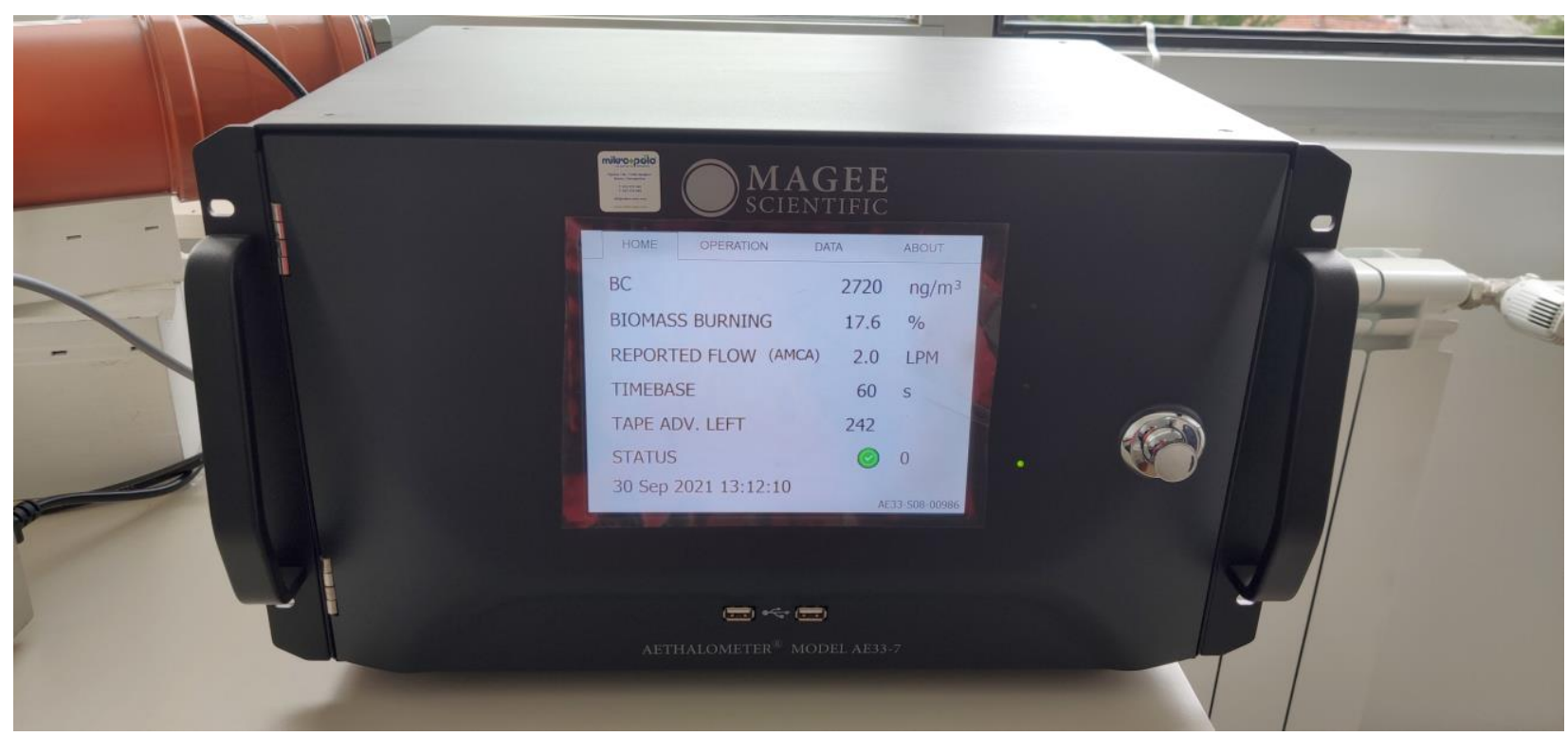

Fig. 1. The aethalometer.

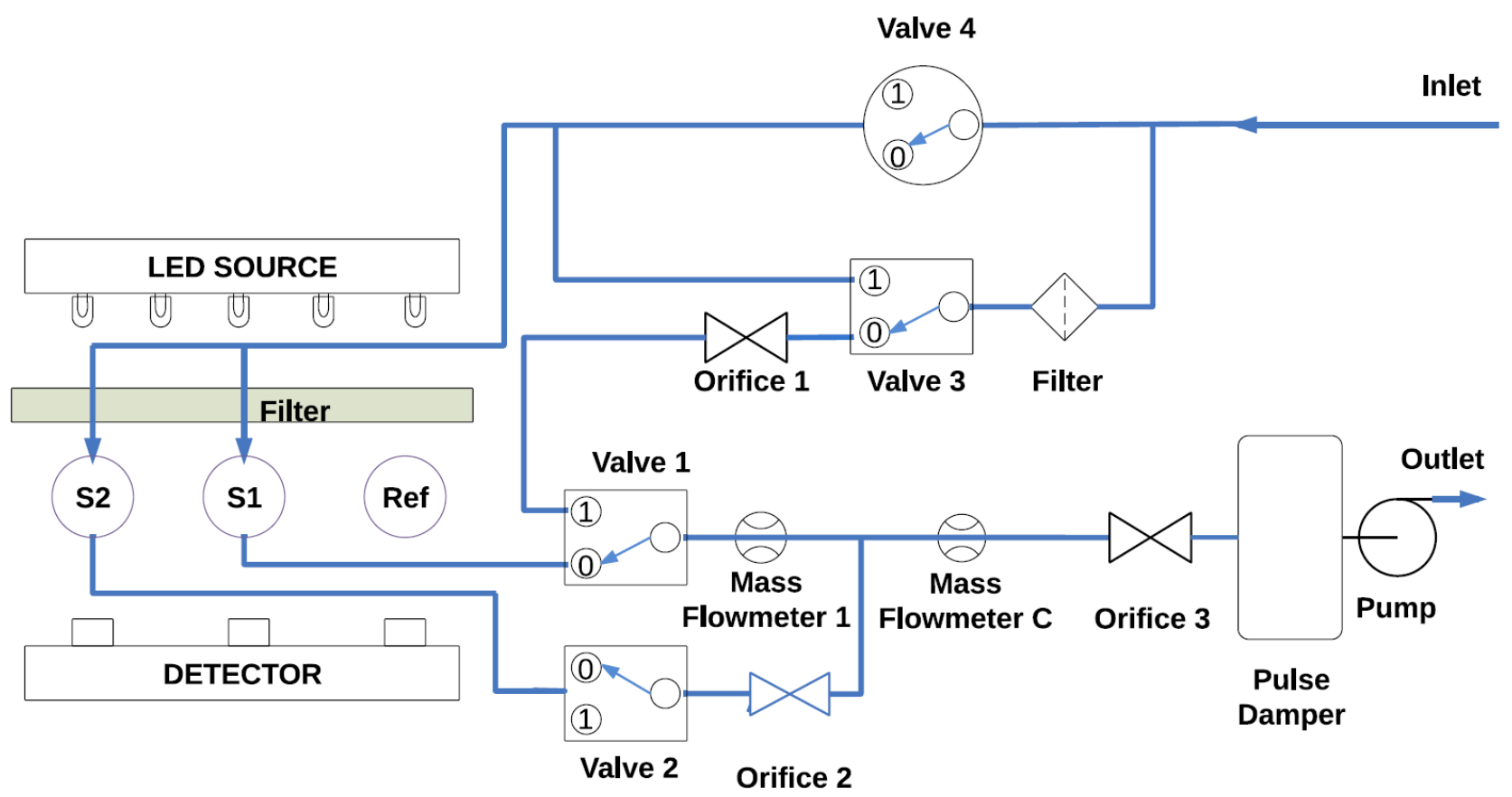

Fig. 2. AE33 flow diagram (image source: AE33 user manual)

\section{Measurements of black carbon in Sarajevo}

The test facility is located at the Faculty of Mechanical Engineering in Sarajevo (Figure 3). The average concentration of $\mathrm{BC}$ in the period 27.11.2020 - 31.5.2021 was $5,67 \mu \mathrm{g} / \mathrm{m}^{3}$, or $14,82 \%$ of total $\mathrm{PM}_{2.5}$ mass. Figure 4 shows the daily average values of $\mathrm{BC}$ concentrations. Since we have measurements from all 7 wavelengths of light, we can calculate the Angstrom exponent [12]. If we assume that value 1 corresponds to liquid fuel (diesel) and value 2 of Angstrom exponent corresponds to biomass burning, we can estimate the biomass burning percentage in total BC mass (Figure 5). From Figure 5 we can see that up to $70 \%$ of $\mathrm{BC}$ comes from burning solid fuels in the winter (domestic heating season), and only around $20 \%$ in May, when the majority of BC comes from diesel engines. 


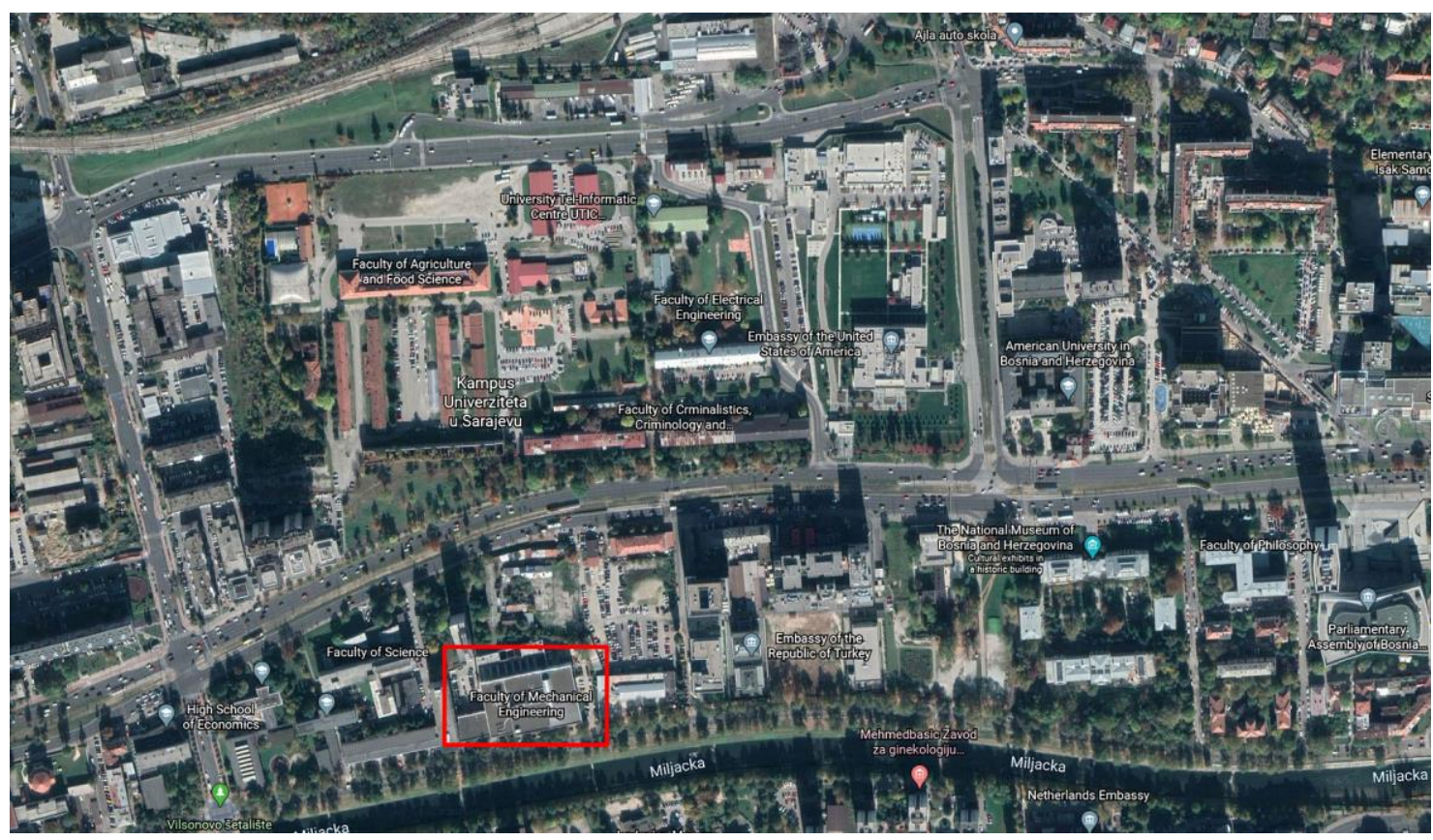

Fig. 3. The location of measurements.

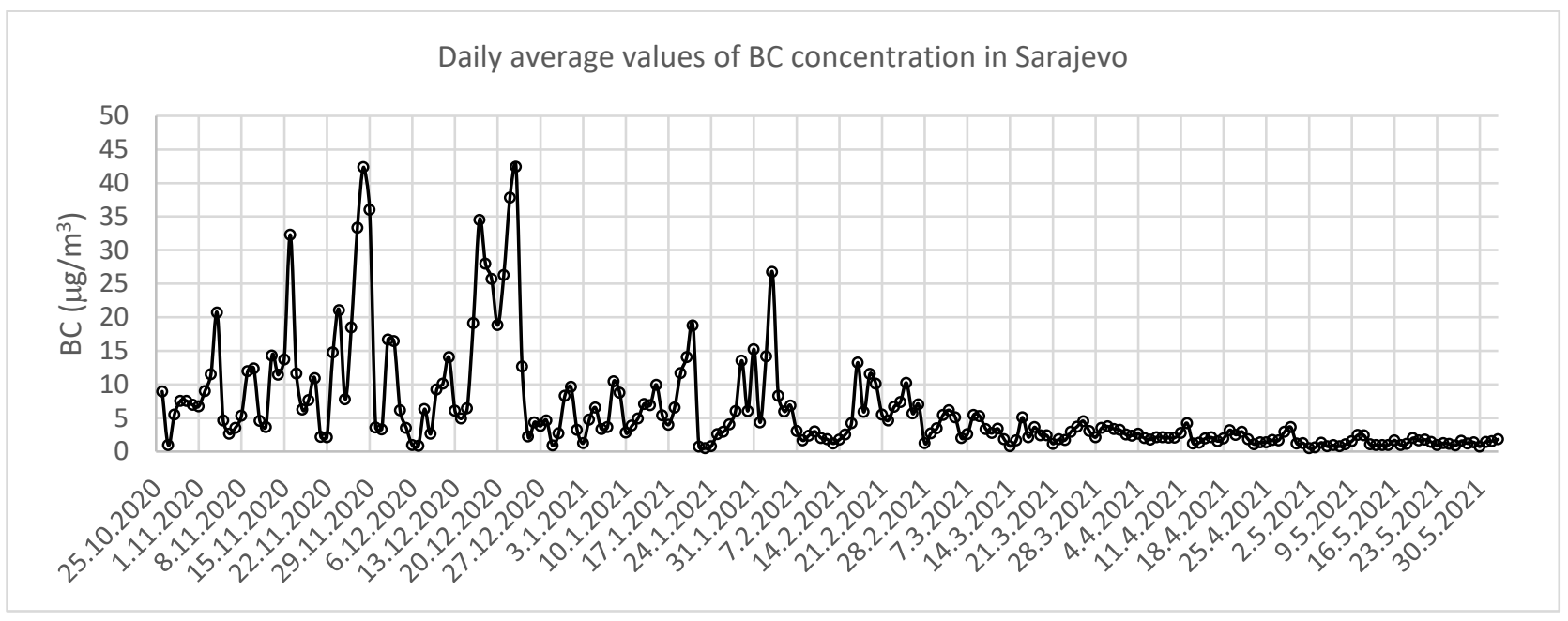

Fig. 4. Daily average values.



Fig. 5. Biomass burning percentage. 
Figure 5 also shows significant noise in the results, which should be investigated in more details. But even though this is a rough estimate, this method is a very promising tool for source apportionment of BC.

\section{Conclusion}

The AE33 aethalometer was successfully used for continuous measurement of BC concentration in Sarajevo from 27.11.2020 - 31.5.2021. The average value of BC concentration was 5,67 $\mu \mathrm{g} / \mathrm{m}^{3}$, or $14,82 \%$ of total $\mathrm{PM}_{2.5}$ mass. Angstrom exponent based source apportionment analysis shows that during the domestic heating season most of the $\mathrm{BC}$ originates from solid fuels, as expected. However, during May, only $20 \%$ of solid fuels and $80 \%$ of liquid fuels contributed to the total BC mass. The Angstrom exponent based source apportionment of BC is a very promising tool and it should be investigated more in future work.

\section{References}

[1] Ramanathan, V. \& Carmichael, Gregory. (2008). Global and Regional Climate Changes Due to Black Carbon. Nat Geosci. 1. DOI: 10.1038/ngeo156.

[2] Bond, T. C. et al. (2013), Bounding the role of black carbon in the climate system: A scientific assessment, J. Geophys. Res. Atmos., 118, 5380- 5552, DOI: 10.1002/jgrd.50171.

[3] Bové, H.; Bongaerts, E.; Slenders, E. et al. (2019). Ambient black carbon particles reach the fetal side of human placenta. Nat Commun 10, 3866 (2019). DOI: 10.1038/s41467-019-11654-3

[4] Janssen, N. A.; Hoek, G.; Simic-Lawson. M.; Fischer, P.; van Bree, L.; ten Brink, H.; Keuken, M.; Atkinson, R. W.; Anderson, H. R.; Brunekreef, B. \& Cassee, F. R. (2011). Black carbon as an additional indicator of the adverse health effects of airborne particles compared with PM10 and PM2.5. Environ Health Perspect. 119(12):1691-9. DOI: 10.1289/ehp.1003369

[5] Arnott, W. P.; Hamasha, K.; Moosmüller, H.; Sheridan, P. J. \& Ogren, J. A. (2005). Towards Aerosol LightAbsorption Measurements with a 7-Wavelength Aethalometer: Evaluation with a Photoacoustic Instrument and 3Wavelength Nephelometer, Aerosol Science and Technology, 39:1, 17-29, DOI: 10.1080/027868290901972

[6] Babich, P.; Davey, M.; Allen, G. \& Koutrakis, P. (2000). Method Comparisons for Particulate Nitrate, Elemental Carbon, and PM2.5 Mass in Seven U.S. Cities, Journal of the Air \& Waste Management Association, 50:7, 10951105, DOI: 10.1080/10473289.2000.10464152

[7] Ferrero, L.; Mocnik, G.; Ferrini, B.S.; Perrone, M.G.; Sangiorgi, G. \& Bolzacchini, E. (2011). Vertical profiles of aerosol absorption coefficient from micro-Aethalometer data and Mie calculation over Milan, Science of The Total Environment, Volume 409, Issue 14, 2011, Pages 2824-2837, ISSN 0048-9697, DOI: 10.1016/j.scitotenv.2011.04.022.

[8] Ning, Z.; Chan, K.L.; Wong, K.C.;.Westerdahl, D.; Močnik, G.; Zhou, J..H. \& Cheung, C. S. (2013). Black carbon mass size distributions of diesel exhaust and urban aerosols measured using differential mobility analyzer in tandem with Aethalometer, Atmospheric Environment, Volume 80, 2013, Pages 31-40, ISSN 1352-2310, DOI: 10.1016/j.atmosenv.2013.07.037.

[9] Wang, Y.; Hopke, P. K.; Rattigan, O. V.; Xia, X.; Chalupa, D. C. \& Utell, M. J. (2011). Characterization of Residential Wood Combustion Particles Using the Two-Wavelength Aethalometer Environmental Science \& Technology 201145 (17), 7387-7393, DOI: 10.1021/es2013984

[10] Pan, X.; Kanaya, Y.; Taketani, F.; Miyakawa, T.; Inomata, S.; Komazaki, Y.; Tanimoto, H.; Wang, Z.; Uno, I. \& Wang, Z. (2017). Emission characteristics of refractory black carbon aerosols from fresh biomass burning: a perspective from laboratory experiments, Atmos. Chem. Phys., 17, 13001-13016, DOI: 10.5194/acp-17-130012017

[11] Zotter, P.; Herich, H.; Gysel, M.; El-Haddad, I.; Zhang, Y.; Močnik, G.; Hüglin, C.; Baltensperger, U.; Szidat, S. \& Prévôt, A. S. H. (2017). Evaluation of the absorption Ångström exponents for traffic and wood burning in the Aethalometer-based source apportionment using radiocarbon measurements of ambient aerosol, Atmos. Chem. Phys., 17, 4229-4249, DOI: 10.5194/acp-17-4229-2017

[12] Masic, A.; Bibic, D.; Kamenica, I.; Bektesevic, J.; Haziabdic, V. \& Mehuljic, M. (2020). Mobile Measurements of Black Carbon for Source Apportionment Studies, Proceedings of the 31st DAAAM International Symposium, pp.0227-0231, B. Katalinic (Ed.), Published by DAAAM International, ISBN 978-3-902734-29-7, ISSN 1726-9679, Vienna, Austria DOI: 10.2507/31 st.daaam.proceedings.031

[13] Masic, A.; Bibic, D.; Pikula, B. \& Razic, F. (2018). New approach of measuring toxic gases concentrations: principle of operation, Proceedings of the 29th DAAAM International Symposium, pp.0882-0887, B. Katalinic (Ed.), Published by DAAAM International, ISBN 978-3-902734-20-4, ISSN 1726-9679, Vienna, Austria, DOI: 10.2507/29th.daaam.proceedings. 127

[14] Bibic, D.; Pikula, B.; Masic, A. \& Razic, F. (2018). New approach of measuring toxic gases concentrations: application examples, Proceedings of the 29th DAAAM International Symposium, pp.0876-0881, B. Katalinic (Ed.), Published by DAAAM International, ISBN 978-3-902734-20-4, ISSN 1726-9679, Vienna, Austria, DOI: $10.2507 / 29$ th.daaam.proceedings. 126 
[15] Masic, A.; Pikula, B.; Bibic, D.; Musemic, R. \& Halac, A. (2018). Calibration and Assessment of Low-cost Dust sensors, Proceedings of the 29th DAAAM International Symposium, pp. 523-528, B. Katalinic (Ed.), Published by DAAAM International, ISBN 978-3-902734-xx-x, ISSN 1726-9679, Vienna, Austria, DOI: 10.2507/29th.daaam.proceedings.075

[16] Masic, A.; Bibic, D. \& Pikula, B. (2019). On the applicability of low-cost sensors for measurements of aerosol concentrations, Proceedings of the 30th DAAAM International Symposium, pp.0452-0456, B. Katalinic (Ed.), Published by DAAAM International, ISBN 978-3-902734-22-8, ISSN 1726-9679, Vienna, Austria DOI: 10.2507/30th.daaam.proceedings.060

[17] Masic, A.; Pikula, B. \& Bibic, D. (2017). Mobile Measurements of Particulate Matter Concentrations in Urban Area, Proceedings of the 28th DAAAM International Symposium, pp.0452-0456, B. Katalinic (Ed.), Published by DAAAM International, ISBN 978-3-902734-11-2, ISSN 1726-9679, Vienna, Austria DOI: 10.2507/28th.daaam.proceedings.063

[18] Masic, A.; Bibic, D.; Pikula, B.; Dzaferovic-Masic, E. \& Razic, F. (2018). Visualization of Data from Network of Sensors: Appropriate Spatial Interpolation Method, Proceedings of the 29th DAAAM International Symposium, pp.0529-0533, B. Katalinic (Ed.), Published by DAAAM International, ISBN 978-3-902734-20-4, ISSN 1726-9679, Vienna, Austria DOI: 10.2507/29th.daaam.proceedings.076

[19] Masic. A.; Bibic, D.; Pikula, B.; Blazevic, A.; Huremovic, J. \& Zero, S. (2020). Evaluation of optical particulate matter sensors under realistic conditions of strong and mild urban pollution. Atmospheric Measurement Techniques, 13, 6427-6443, DOI: 10.5194/amt-13-6427-2020

[20] Masic, A.; Pikula, B.; Haziabdic, V.; Mehuljic, M. \& Bektesevic, J. (2020). Evaluation of Face Mask Filtering Efficiency Using High-End Scanning Mobility Particle Sizer, Proceedings of the 31st DAAAM International Symposium, pp.0224-0226, B. Katalinic (Ed.), Published by DAAAM International, ISBN 978-3-902734-29-7, ISSN 1726-9679, Vienna, Austria DOI: 10.2507/31st.daaam.proceedings.030

[21] Masic, A.; Kepnik, G.; Bektesevic, J.; Mehuljic, M.; Saric, I. \& Haziabdic, V. (2020). The Network of Smart Sensors for Indoor Air Quality Monitoring, Proceedings of the 31st DAAAM International Symposium, pp.0232-0235, B. Katalinic (Ed.), Published by DAAAM International, ISBN 978-3-902734-29-7, ISSN 1726-9679, Vienna, Austria DOI: $10.2507 / 31$ st.daaam.proceedings.032 